\title{
COMMENTARY
}

\section{Estrogen actions in the ovary revisited}

\author{
K L Britt and J K Findlay \\ Prince Henry's Institute of Medical Research, PO Box 5152, Clayton, Victoria 3168, Australia \\ (Requests for offprints should be addressed to J Findlay; Email: jock.findlay@med.monash.edu.au)
}

\begin{abstract}
Estrogens are synonymous with fertility and infertility in mammals. Our knowledge of the biological actions of estrogens, however, is incomplete. Three recent developments have thrown new light on the actions of estrogens in mammalian reproduction that will lead to a greater understanding of their functions. They are (a) the identification of a second estrogen receptor, called $\operatorname{ER} \beta$, (b) the identification of ligand-specific ER coactivators and (c) mouse models with targeted disruption of the genes encoding both ER and the aromatase enzyme. These models provide for the first time animals which are either unable to respond to endogenous or exogenous estrogens (ER 'knockouts'), or can respond to exogenous estrogen but do not make endogenous estrogen (aromatase 'knockout' or ArKO). Furthermore, the ArKO mouse has provided a model to study the effects on the ovary of exogenous estrogens of plant and synthetic origin that are of clinical relevance. The data show that estrogens are essential for fertility but not for survival after birth or for
\end{abstract}

the formation of the reproductive tract. This commentary focuses on the roles of estrogen in folliculogenesis and in the maintenance of the ovarian somatic cell phenotype in the mouse. We also hypothesize that the $\operatorname{ER} \alpha$ and $\operatorname{ER} \beta$ may subserve the proliferative and differentiative actions of estrogen, respectively, within a follicle. In summary, estrogen is obligatory for normal folliculogenesis beyond the antral stage and for the maintenance of the female phenotype of the somatic cells within the ovaries. This clearly demonstrates a major role for sex steroids in somatic cell differentiation in the gonads of eutherian mammals and challenges the central paradigm that the ovary is the default gonad, arising due to the absence of testicular defining signals. Evidence is also provided for the plasticity of the adult female gonad. Understanding the mechanisms of estrogen actions will provide an insight into the regulation of reproductive disorders afflicting women today, notably ovarian dysfunction and the menopause.

Journal of Endocrinology (2002) 175, 269-276

\section{Introduction}

Estrogens are synonymous with fertility and infertility in mammals. They were isolated originally as endocrine steroid hormones produced by the gonads and placenta that had negative and positive feedback influences on the hypothalamic-pituitary axis (Diczfalusy \& Fraser 1998). It was established that estrogens could also have local influences on the uterus and within the gonads (Hisaw 1947). These properties of estrogen were exploited in the development of the contraceptive pill for women, which combines synthetic estrogens with a progestogen (Pincus et al. 1958). An estrogen receptor (ER) was subsequently identified in target cells and found to act as a nuclear transcription factor responsible for transmitting the genomic actions of estrogenic compounds (Jensen \& DeSombre 1973).

Several observations, however, showed that our knowledge of the biological actions of estrogens was incomplete. Compounds developed and used as agricultural pesticides and for the plastics industry were shown to have estrogenic activity that could lead to infertility and tumors in animals including humans (Sharara et al. 1998). Treatment of pregnant women with diethylstilbestrol (DES) led to malformation of the reproductive tracts of their children, which included the development of vaginal cancer (Swan 2000). The actions of phytoestrogens used in hormone replacement therapy (Adlercreutz 1995) could not be explained in terms of known mechanisms of estrogen action. Finally, synthetic estrogens were observed to have diverse biological effects in different target tissues that were not explicable by the current knowledge of estrogen action through a single receptor (McDonnell et al. 2001).

Three recent developments have thrown new light on the actions of estrogens in mammalian reproduction. They are (a) the identification of a second estrogen receptor, called ER $\beta$ (Kuiper et al. 1996), (b) the identification 
of ligand-specific ER coactivators (Onate et al. 1995, McKenna et al. 1999), which may also show some ER isoform specificity (see McDonnell et al. 2000) and (c) mouse models with targeted disruption of the genes encoding for both ER (Lubahn et al. 1993, Krege et al. 1998, Couse et al. 1999a, Dupont et al. 2000), and for the aromatase enzyme (Fisher et al. 1998, Honda et al. 1998, Toda et al. 2001) responsible for the synthesis of estrogen. Importantly, these models provide for the first time animals which are either unable to respond to endogenous or exogenous estrogens (ER 'knockouts'), or can respond to exogenous estrogen but do not make endogenous estrogen (aromatase 'knockout' or ArKO). The data show that although estrogens are not obligatory for survival after birth, or for the formation of the reproductive tract, they are essential for normal fertility in both males and females. Furthermore, the ArKO mouse has provided a model to study the effects on the ovary of exogenous estrogens of plant and synthetic origin that are of clinical relevance. This commentary focuses on the roles of estrogen in folliculogenesis and in the maintenance of the ovarian somatic cell phenotype in the mouse.

\section{Folliculogenesis}

Follicles form in the ovary when developmentally arrested germ cells or oocytes recruit somatic follicular cells and organize into discrete 'resting' primordial follicles. This somatic cell investment maintains the oocyte in the diplotene stage of the first meiotic prophase, in the case of women, for up to 40-50 years. These follicles evolve through a complex series of proliferative and differentiative steps called folliculogenesis, to a structure and state where ovulation is feasible, or they succumb to atresia and die. Females have a finite number of 'resting' follicles at birth, which decrease thereafter. We still do not know what controls the reactivation of a few of these primordial follicles to enter the committed growth phase each day. There is important cross talk between the oocyte and the somatic cells (Canipari 2000) and between the somatic cells themselves. These autocrine and paracrine influences (Findlay 1993) regulate follicular growth and differentiation. The current evidence suggests that the preantral stages of committed follicles (primary and secondary) are dependent on local regulators, with gonadotropins having a facilitatory role. The reverse is true for the antral (tertiary and Graafian) follicles, where gonadotropins are essential for development, and locally produced hormones and growth factors play a facilitatory role (Findlay 1993, Scaramuzzi et al. 1993, Monget \& Bondy 2000). Nevertheless, each follicle is considered to have a unique biological makeup that makes it different from every other follicle. In women it takes up to 6 months for a reactivated primary follicle to reach the ovulatory stage. This exceedingly rare event occurs in less than 1 in 100 follicles, with the remainder succumbing to atresia either via oocyte or granulosa cell apoptosis (Hsu \& Hsueh 2000, Reynaud \& Driancourt 2000).

Estrogen has acknowledged local intrafollicular actions (Hisaw 1947, Richards 2001). Estrogens act via two types of receptors, $\mathrm{ER} \alpha$ and $\mathrm{ER} \beta$, and have direct proliferative and differentiative influences on follicle development, depending on the stage of folliculogenesis (Drummond \& Findlay 1999). The ovary contains both ER subtypes, with a predominance of ER $\beta$ over ER $\alpha$ in granulosa cells. Despite an extensive amount of research on the production of estradiol-17 $\beta\left(\mathrm{E}_{2}\right)$, the principal estrogen, by follicles, and the structure and functions of the respective ERs, the specific role(s) of $E_{2}$ and its receptors in serving the different actions of estrogen in the ovary have remained elusive (Richards 2001).

The actions of estrogen are intimately related to the actions of follicle-stimulating hormone (FSH) in folliculogenesis. FSH is a key driver of folliculogenesis. It is essential for the final growth of antral follicles (Kumar et al. 1997, Abel et al. 2000) and small growing follicles are responsive to but not dependent on FSH for growth. FSH, together with insulin-like growth factor-I (IGF-I) and $\mathrm{E}_{2}$, stimulates the proliferation and differentiation of granulosa cells (Adashi et al. 1985, Zhou et al. 1997). The specific genes induced in granulosa cells by $\mathrm{E}_{2}$ have not been identified, but it is clear that $\mathrm{E}_{2}$ exerts a supporting role on FSH action. There are several candidate genes suspected of being regulated in granulosa cells by $\mathrm{E}_{2}$. They include cyclin D2 (Richards 2001), inhibin $\alpha$ and inhibin $\beta B$ (Charpentier et al. 2000). Studies on the influence of $E_{2}$ on gene expression in MCF-7 breast cancer cells revealed changes in a number of known and novel genes (Charpentier et al. 2000) that can now be investigated in granulosa cells.

Recent work has shed light on the mechanisms by which IGF-I and $\mathrm{E}_{2}$ interact with $\mathrm{FSH}$ to influence granulosa cells. There is now evidence that in addition to its well characterized actions via the cAMP/protein kinase A (PKA) pathway, FSH stimulates phosphorylation of two closely related kinases that are downstream targets of the IGF-I/phosphatidylinositol 3-kinase (PI3-K)/ phosphatidylinositol-dependent kinase 1 (PDK1) pathway (Richards et al. 2002). These kinases are Sgk (serum and glucocorticoid-induced kinase) and protein kinase B (PKB) or Akt. These effects of FSH, which are independent of cAMP-dependent PKA, can be mimicked by forskolin, cAMP and IGF-I. Targets for PKB and Sgk include members of the forkhead (FOX) family of transcription factors, which are expressed in rodent ovaries (Richards et al. 2002). It has been shown that FSH and $\mathrm{E}_{2}$ enhance expression of the gene for forkhead homolog of rhabdomysarcoma (FKHR) and its protein in granulosa cells of developing follicles (Richards et al. 2002). In the same study, $\mathrm{E}_{2}$ also enhanced expression of other IGF-I pathway components and ER $\beta$, indicating that $E_{2}$ and 
IGF-I may form an autocrine regulatory network within growing follicles. It has been suggested that FKHR expression may be linked to the proliferation of granulosa cells given that cells expressing FKHR were highly proliferative, expressed high levels of cyclin D2 (Robker \& Richards 1998a) and ER $\beta$ (Sharma et al. 1999) and showed increased staining for proliferating cell nuclear antigen (PCNA)/BrdU (Robker \& Richards 1998b). The targets of FKHR in granulosa cells are not yet known. The IGF-I/PDK1/PKB pathway is associated with cell survival, which suggests that $\mathrm{FSH}$, enhanced by $\mathrm{E}_{2}$, may have the capacity to influence cell survival, while at the same time, via PKA, FSH can impact on differentiation events in granulosa cells.

The advent of the ER $\alpha$ knockout (ERKO), ER $\beta$ knockout (BERKO), compound ER $\alpha \beta$ knockout and ArKO mice offer an opportunity to define the actions of estrogen in folliculogenesis in a more exacting way. ERKO mice are acyclic, infertile and possess hyperemic ovaries devoid of corpora lutea (Couse \& Korach 1999a). Folliculogenesis is arrested at the antral stage with large secondary follicles becoming cystic and hemorrhagic within 3 weeks of birth. The ovarian phenotype manifests in the presence of elevated luteinizing hormone $(\mathrm{LH})$ levels. In contrast, BERKO females have small ovaries, some arrested follicular development and their fertility is compromised with reduced numbers of offspring per litter, consistent with the reduced number of corpora lutea observed (Krege et al. 1998). Gonadotropin levels are normal in these mice. Thus, the extent of follicular development is greater in BERKO than ERKO mice (Couse \& Korach 1999b). The ERKO mice have a block in folliculogenesis at the early antral stage before the increase in granulosa cell proliferation (Hirshfield 1991), whereas the BERKO mice have antral follicles and can ovulate (Krege et al. 1998). We hypothesize therefore, that the proliferative actions of $\mathrm{E}_{2}$ require $\mathrm{ER} \alpha$, whereas the differentiative (and antiproliferative) effects of $\mathrm{E}_{2}$ are mediated principally by ER $\beta$.

The hypothesis that $\operatorname{ER} \alpha$ subserves the proliferative actions of $E_{2}$ has support from other experimental paradigms. BERKO mice show increased cell proliferation and an exaggerated response to $\mathrm{E}_{2}$ in the uterus (Weihua et al. 2000), leading the authors to conclude that ER $\beta$ modulates the effects of ER $\alpha$, and in addition, or as a consequence, has an antiproliferative function in the immature uterus. Studies on the prostate in BERKO mice suggest that activating ligands specific for $\operatorname{ER} \beta$ could be important modulators of prostatic epithelial growth and differentiation (Weihua et al. 2001). Jarred et al. (2002) concluded that $\mathrm{ER} \alpha$ is the predominant receptor mediating the mitogenic actions of estrogen in the mouse prostate, although they indicated that a role for ER $\beta$ remained to be defined. There is also evidence from studies on trabecular bone that $\operatorname{ER} \beta$ acts in a repressive manner, possibly by counteracting the stimulatory action of ER $\alpha$ on bone formation (Windahl et al. 2001). Recently, Liu et al. (2002) described direct evidence for opposing actions of ER $\alpha$ and $\operatorname{ER} \beta$ on cyclin D1 gene expression in HeLa cells. These authors concluded that ER $\beta$ may modulate the proliferative effects of ER $\alpha$ by blocking its action at the cyclin D1 gene or at other key pro-proliferative target genes.

This raises important questions about the mechanisms by which ER $\alpha$ and $\operatorname{ER} \beta$ interact in response to agonist or antagonist stimulation. If both $\operatorname{ER} \alpha$ and $\operatorname{ER} \beta$ reside within the same cell type, there may be either homo- or heterodimerization, with heterodimerization believed to be a preferred option (see Drummond \& Findlay 1999). In this model, it can be predicted that activation through a heterodimer of the ER would allow ER $\beta$ to exert its modulatory actions. If ER $\beta$ and ER $\alpha$ reside in different cell types and only form homodimers within those cell types, a modulatory action of $\operatorname{ER} \beta$ on $\mathrm{ER} \alpha$ would not be possible and a different model, one where paracrine factors are involved, becomes more plausible. The cellular distribution of $E R \alpha$ and $E R \beta$ will be an important determinant of $E_{2}$ action in the ovary. At present there are differences in the literature about the presence of $E R \alpha$ protein in granulosa cells, cells that contain abundant ER $\beta$ protein for example (Sar \& Welsch 1999, Sharma et al. 1999). Similarly in rat prostate, low levels of ER $\alpha$ are present in the stroma but are not detectable in the epithelium (Cooke et al. 1997), whereas ER $\beta$ is localized in the epithelium (Kuiper et al. 1996).

The ArKO mouse (on an estrogen-free diet) has allowed us to define how far follicles can grow in the total absence of estrogen before becoming atretic (Fisher et al. 1998, Britt et al. 2000). As a consequence, we were able to describe the effect of hypoestrogenicity on the relative sizes of populations of different follicles (Britt et al. 2000). Female ArKO mice have undetectable levels of aromatase and estrogens whilst exhibiting high levels of serum testosterone, FSH and LH. These reproductive hormones have been implicated as playing crucial roles in various aspects of folliculogenesis. Not surprisingly, these ArKO mice are infertile with folliculogenesis arrested at the antral stage, and an absence of corpora lutea (Fig. 1). In 6-weekold ArKO mice, the ovaries contained an apparent increase in the numbers of secondary and antral follicles. The antral follicles that were present appeared morphologically atretic or prematurely luteinized as evidenced by the presence of pyknotic nuclei or cytoplasmic lipid droplets respectively. The ovaries exhibited an increasingly diffuse interstitium (with age) and contained increasing proportions of morphologically abnormal follicles containing cells resembling Sertoli cells (Fig. 1). The appearance of these abnormal follicles was delayed by phytoestrogens present in soy meal contained within the mouse chow (Britt et al. 2002a). Toda et al. (2001) also reported depletion of follicles and formation of hemorrhagic cysts in their ArKO mouse model at 5 months of age. They subsequently 



Figure 1 (A) The morphology of a wild-type mouse ovary: typical follicles consisting of growing oocytes (o) surrounded by layers of proliferating granulosa cells (gc). The granulosa cells possess the typical low cytoplasmic-to-nuclear ratio. In maturing follicles antral spaces (a) form within the granulosa cell layer. The interstitial region (i) is comprised of stromal and interstitial cells. (B) Morphology of a mouse ovary with a deletion in the aromatase gene (ArKO), at 16 weeks of age, maintained on a soy-free diet. The arrowhead and arrow depict the nucleus and cytoplasm respectively of somatic cells resembling Sertoli cells. These cells possess a high cytoplasmic-to-nuclear ratio with cytoplasmic extensions (arrow). Triangles signify lacunae, which have been identified as the remnants of primary follicles, presumably dying atretic follicles. Other follicles transform into hemorrhagic cysts (cy). The blue appearance of the interstitium in comparison with the wild-type ovary represents the increased deposition of collagen to these degenerating ovaries. Scale bar $=0 \cdot 1 \mathrm{~mm}$. Adapted from Britt et al. 2002a with permission from FASEB Journal and all coauthors.

reported that the addition of bisphenol A, a zenoestrogen, to the diet prevented the formation of cysts and follicle loss, but failed to restore ovulatory capacity given that no corpora lutea were present (Toda et al. 2002).
In summary, these 'knockout' mouse models show that estrogen is obligatory for normal folliculogenesis beyond the antral stage.

\section{Phenotype of ovarian somatic cells}

The central dogma of mammalian sex determination states that testicular differentiation and subsequent male development occurs as a result of the sex-determining gene on the $\mathrm{Y}$ chromosome (Sry), which acts as a molecular switch in embryos having an XY chromosome constitution (Capel 1996). In non-mammalian vertebrates, alternative mechanisms of sex determination occur, which are dependent on factors in the external biological environment. These factors include temperature, and more importantly, aromatase activity (Desvages \& Pieau 1992, Desvages et al. 1993). The role of estrogen in gonadal differentiation and maintenance of the ovarian phenotype of somatic cells in eutherian mammals has not been clearly established (Wilson et al. 1981, Pieau et al. 1994). Accounts of natural and experimental differentiation of male somatic cells have been reported in XX gonads under conditions of variable estrogen deficiency. Seminiferous tubule-like structures have been observed in freemartin cattle (Jost et al. 1973), following premature oocyte death (Hashimoto et al. 1990), and in XX gonads of $\mathrm{W} / \mathrm{W}^{\mathrm{v}}$ mutant mice, and busulphan-treated rats (Merchant 1975, Merchant-Larios \& Centeno 1981). They have also been observed in fetal rodent ovaries transplanted into male hosts (Buyse 1935) and in aging rodents (Engle 1946, Crumeyrolle-Arias et al. 1976). The transdifferentiation of ovarian somatic cells to a testicular phenotype in these examples has been ascribed to the absence of viable oocytes (Hashimoto et al. 1990, McLaren 1991), rather than to the involvement of steroid hormones. A role for estrogen in the phenotype of the somatic cell is suggested in mice deficient in both types of functional ER $(\mathrm{ER} \alpha \beta \mathrm{KO})$ (Couse et al. 1999, Dupont et al. 2000). In this model, seminiferous tubule-like structures develop in the gonads with concomitant oocyte loss and expression of Sox 9 and MIS, genes associated with testis formation. These compound knockouts also exhibit ectoplasmic specialisations between the Sertoli-like cells (Dupont et al. 2000), which are indicative of a male phenotype. The inability of estrogen to transduce a genomic signal in these animals, however, precludes replacement studies to investigate the role of estrogen in the development and maintenance of female somatic cells within XX ovaries.

The ArKO mouse, however, has allowed us to assess the role played by steroid hormones in the sexual differentiation of mammals. In the absence of a $\mathrm{Y}$ chromosome (or Sry region), estrogen-deficient ArKO female mice develop masculinized gonads (Table 1; Britt et al. 2001, 2002a). Cells morphologically resembling testicular Leydig cells were present within the interstitial regions of 
Table 1 Ultrastructural characteristics of somatic cells in the ovaries of wild-type mice (WT), and mice with a deletion in the aromatase gene (ArKO) in comparison with wild-type testes

\begin{tabular}{|c|c|c|c|}
\hline & $\begin{array}{l}\text { Testis } \\
\text { WT }\end{array}$ & $\begin{array}{l}\text { Ovary } \\
\text { ArKO }\end{array}$ & $\begin{array}{l}\text { Ovary } \\
\text { WT }\end{array}$ \\
\hline \multicolumn{4}{|l|}{ Tubular/follicular region } \\
\hline High cytoplasmic-to-nuclear ratio & Yes & Yes & No \\
\hline Tripartite nucleoli & Yes & Yes & No \\
\hline Cytoplasmic extensions & Yes & Yes & No \\
\hline Ectoplasmic specializations & Yes & Yes & No \\
\hline \multicolumn{4}{|l|}{ Interstitial region } \\
\hline \multicolumn{4}{|l|}{ Smooth endoplasmic reticulum } \\
\hline Extensive & Yes & Yes & No \\
\hline Whorls & Yes & Yes & No \\
\hline Large cytoplasm & Yes & Yes & Occasionally \\
\hline Annular nucleoli & Yes & Yes & No \\
\hline Steroidogenic mitochondria & Yes & Yes & Yes \\
\hline Lamellar cristae & No & No & Yes \\
\hline Tubulo-vesicular cristae & Yes & Yes & No \\
\hline
\end{tabular}

Adapted from Britt et al. 2002a.

6-week-old ArKO ovaries. Their numbers increased as a function of age. At 16-18 weeks of age, few healthy preantral follicles were observed, and folliculogenesis was blocked at the primordial stage in several individuals. Detailed light microscopy identified abnormal follicles as seminiferous tubule-like structures filled with Sertolilike somatic cells, apparently arising from the trans/ re-differentiation of granulosa cells. There were specialized desmosome-like adherens junctions and Sertoli-cell specific, ectoplasmic specializations between these Sertolilike cells (Table 1, Fig. 2). Espin, an actin bundling protein present in these ectoplasmic specializations, was detected in wild-type testis and ArKO abnormal follicles but was absent in follicles of wild-type ovaries. We also showed that consistent with the appearance of Sertoli cells, the ovaries of ArKO mice expressed levels of Sox 9 mRNA similar to those observed in wild-type testis, whilst significantly higher than in wild-type ovaries. This extends recent observations (Couse et al. 1999) of increased Sox9 expression in ovaries of ER $\alpha \beta K O$ mice with similar Sertoli cell-like structures. Sox9 expression has also been associated with Sertoli cell development in 'oddsex' mice (Bishop et al. 2000) and in female intersex chick gonads (Vaillant et al. 2001). Genetically female (XX) mice overexpressing Sox9 also contain Sertoli-like cells in their ovaries (Vidal et al. 2001). Furthermore, the increased (a)
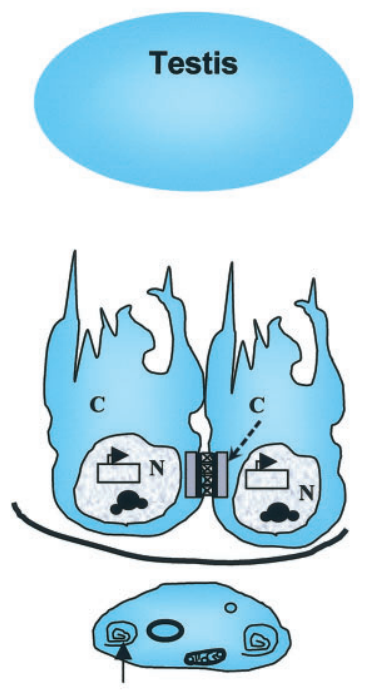

(b)
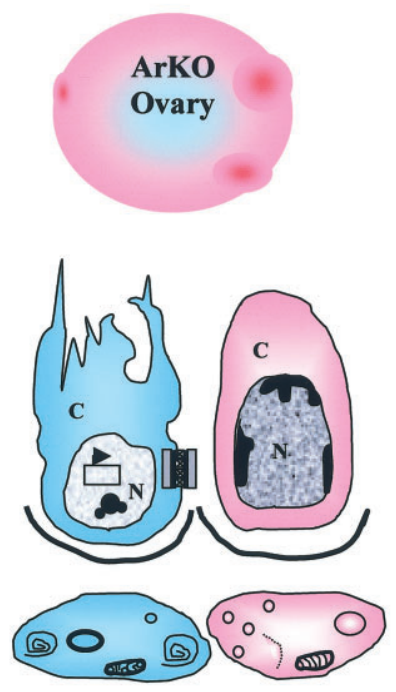

(c)
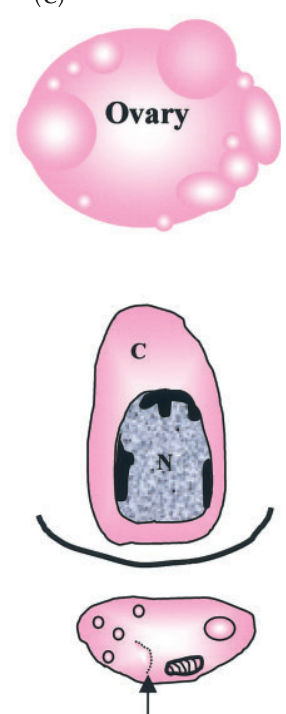

Figure 2 Schematic diagram depicting the ultrastructural characteristics of the somatic cells of the gonad. (A) Testes possess Sertoli cells within the seminiferous tubules of the testes. The Sertoli cells have a high cytoplasmic (C)-to-nuclear $(\mathrm{N})$ ratio and homogeneous chromatin distribution. Mature cells possess defined, and in some cases tripartite nucleoli. The nucleus also expresses Sox9. Between adjacent Sertoli cells are fence-like cell-specific junctions called ectoplasmic specializations (dashed arrow). These junctions possess immunopositive espin protein. The Leydig cells are present in the interstitial area. They characteristically contain whorls of endoplasmic reticulum (arrow), tubulo-vesicular mitochondrial cristae, annular nuclei (bold oval) and some lipid. (B) The gonads of the female ArKO mice possess both the ovarian (C) and testicular (A) somatic cells.

(C) Granulosa cells of the ovary possess a small cytoplasm (C)-to-nuclear (N) ratio with heterogeneous chromatin distribution. The interstitial cells possess lipid (small circles), endoplasmic reticulum (arrow) and lamellar mitochondrial cristae. 
collagen deposition observed in the ArKO ovaries correlates with the regulation of the collagen type 1 by Sox 9 ( $\mathrm{Ng}$ et al. 1997).

Estradiol replacement in 7-week-old ArKO female mice, for 3 weeks, prevented the onset of the male phenotype of somatic cells (Britt et al. 2002a). Toda et al. (2001) reported that ArKO mice treated with estrogen from 4 weeks of age reversed the accumulation of smooth endoplasmic reticulum in luteinized interstitial cells. However, these cells were not definitively identified and the authors did not comment on the appearance of Sertoli-like cells in the ArKO ovary. We have shown that these luteinized interstitial cells are ultrastructurally similar to Leydig cells and that estrogen replacement ameliorated their appearance, in addition to suppression/reversal of the appearance of the tubular structures containing Sertoli-like cells.

This data confirms and extends observations in ER $\alpha \beta K O$ mice in which Sertoli-like cells with similar properties were observed in the ovaries (Couse et al. 1999, Dupont et al. 2000). These compound knockouts are not estrogen-free and it is possible that there remains an influence of estrogen via some, as yet unidentified, ER or through a non-genomic action of $E_{2}$. Our observation of Sertoli-like cells in the ovaries of ArKO mice on a phytoestrogen-free diet unequivocally shows that these cells develop in the complete absence of estrogen (Fig. 2). The presence of cells morphologically resembling Leydig cells in the interstitium of ArKO ovaries is a novel observation not previously reported in ER mutant mice.

A major role for sex steroids in the somatic cell differentiation of ovaries of eutherian mammals has been demonstrated by studies of the ArKO mouse ovary. These findings also challenge the central paradigm that the ovary is the default gonad arising due to the absence of testicular defining signals. Estrogen is clearly required for the female-type phenotype of the somatic cells within the mammalian ovaries. Evidence for the plasticity of the adult female gonad has been provided.

\section{Androgen action in models of hypoestrogenicity}

The possibility remains that some or all of the ovarian phenotype in these mouse models of hypoestrogenicity is due to inappropriate actions of androgens on the ovary. This could be mediated through either elevated levels of serum androgens as in the ArKO mice (Fisher et al. 1998), or inappropriate expression of the androgen receptor (AR) as in the BERKO mice (Cheng et al. 2002).

Androgen action in the ovary is thought to be a two-stage process (Hillier \& Tetsuka 1997). In committed preantral follicles, testosterone or dihydrotestosterone of thecal origin acts via AR located principally in the granulosa cells to facilitate proliferation and FSH action. Once antral follicles are formed, there is a decrease in expression of AR in granulosa cells and increased utiliz- ation of androgen as a substrate for aromatase activity. Maintenance of AR and failure to express aromatase in the granulosa cells of antral follicles is characterized by a high androgen-to-estrogen ratio in the follicular fluid (Carson et al. 1981, Maxson et al. 1985), and leads to atresia.

Ovaries of BERKO mice, which contain many atretic follicles and a block in folliculogenesis at the antral stage, express AR aberrantly (Cheng et al. 2002). Treatment of BERKO mice with the AR antagonist, flutamide, partially reversed the phenotype by restoring folliculogenesis but not ovulation. Cheng et al. (2002) concluded that expression of ER $\beta$ was necessary for the downregulation of $\mathrm{AR}$ in antral follicles in order to prevent atresia and provide sufficient androgen substrate for conversion to estrogen by aromatase in granulosa cells.

AR levels have not been measured in the ERKO, $\alpha \beta E R K O$ or ArKO models. Elevated levels of testosterone have been reported to circulate in ArKO female mice (Fisher et al. 1998), but, to our knowledge, androgen levels have not been reported in the other models of hypoestrogenicity. It is possible, therefore, that these elevated levels of testosterone in the absence of $\mathrm{E}_{2}$ in $\mathrm{ArKO}$ mice are responsible for the increased numbers of primary follicles, some or all of the advanced atresia and the block in folliculogenesis observed in the ovaries (Britt et al. 2000). It is worth noting that estrogen replacement, either as phytoestrogens in the diet or as estradiol pellets, was sufficient to delay the onset of the phenotype or partially restore folliculogenesis (Britt et al. 2002a). This model would be consistent with an action of estrogen via $\operatorname{ER} \beta$ to downregulate $\mathrm{AR}$ and so reduce atresia, as suggested by Cheng et al. (2002).

\section{Other implications}

In the absence of estrogen, the female-specific phenotype of the ovarian cells is lost and a more testicular type of appearance is noted (Britt et al. 2001, 2002a). This is important in the light of menopausal ovaries which also exist in a state of hypoestrogenism and the fact that testicular tissue has been reported to develop within genetically female ovaries as females age (Engle 1946). There are various reproductive disorders afflicting women today that occur as a result of ovarian dysfunction, and/or ovulatory disorders. An understanding of how estrogen functions provides insight into the hormonal regulation of such ovarian processes, and into the symptoms associated with menopause.

Low levels of dietary phytoestrogens (contained in most commercially available supplements offered to menopausal women) profoundly affect the ovary (Britt et al. 2001, 2002a) and the hypothalamo-pituitary-gonadal axis (Britt et al. 2002b). Maintenance on a soy-containing diet from conception is able to protect the otherwise hypoestrogenic ovary from ensuing testicular development in the ArKO mouse. Thus dietary soya meal, acting as an estrogen 
agonist, and exogenous estrogen treatment postponed the development of male-type cells by the ovary. This has considerable significance, particularly for women undergoing the menopausal transition. Finally, it is well known that Asian populations ingest more soya protein than inhabitants of the so-called 'Western continents' and have a significantly reduced incidence of both breast and prostate cancer. We have shown that this may, at least in part, be the result of a direct action of these estrogenic chemicals on the differentiative status of the cell.

\section{Acknowledgements}

The authors would like to thank Professor Evan Simpson and Drs Ann Drummond and Margaret Jones for their constructive comments. The financial support of the NH\&MRC of Australia Program Grant (RegKey 983212; J K F) and Fellowship (RegKey 198705; J K F) is gratefully acknowledged.

\section{References}

Abel MH, Wootton AN, Wilkins V, Huhtaniemi I, Knight PG \& Charlton HM 2000 The effect of a null mutation in the follicle-stimulating hormone receptor gene on mouse reproduction. Endocrinology 141 1795-1803.

Adashi EY, Resnick CE, D’Ercole AJ, Svoboda ME \& Van Wyk JJ 1985 Insulin-like growth factors as intraovarian regulators of granulosa cell growth and function. Endocrine Reviews 6 400-420.

Adlercreutz H 1995 Phytoestrogens: epidemiology and a possible role in cancer protection. Environmental Health Perspectives 103 (Suppl 7) 103-112.

Bishop CE, Whitworth DJ, Qin Y, Agoulnik AI, Agoulnik IU, Harrison WR, Behringer RR \& Overbeek PA 2000 A transgenic insertion upstream of sox 9 is associated with dominant $\mathrm{XX}$ sex reversal in the mouse. Nature Genetics 26 490-494.

Britt KL, Drummond AE, Cox VA, Dyson M, Wreford NG, Jones ME, Simpson ER \& Findlay JK 2000 An age-related ovarian phenotype in mice with targeted disruption of the Cyp 19 (aromatase) gene. Endocrinology 141 2614-2623.

Britt KL, Kerr JF, O’Donnell L, Jones ME, Drummond AE, Findlay JK \& Simpson ER 2001 Defining the role of sex steroid hormones in the control of differentiation of somatic cells in mammalian gonads. Abstract OR 39-2. 83rd Annual Meeting of the US Endocrine Society, June 2001, Denver Colorado, USA.

Britt KL, Kerr JF, O’Donnell L, Jones ME, Drummond AE, Davis SR, Simpson ER \& Findlay JK 2002a Estrogen regulates development of the somatic cell phenotype in the eutherian ovary. Faseb Journal 16 1389-1397.

Britt KL, Jones ME, Drummond AE, Simpson ER \& Findlay JK $2002 b$ Dietary estrogens have a negative effect on gonadotropin release in estrogen deplete mice. Abstract P2-460. 84th Annual Meeting of the US Endocrine Society, June 2002, San Francisco, CA, USA.

Buyse A 1935 The diferentiation of transplanted mammalian gonad primordia. Journal of Experimental Zoology 70 1-41.

Canipari R 2000 Oocyte-granulosa cell interactions. Human Reproduction Update 6 279-289.

Capel B 1996 The role of Sry in cellular events underlying mammalian sex determination. Current Topics in Developmental Biology 32 1-37.
Carson RS, Findlay JK, Clarke IJ \& Burger HG 1981 Estradiol, testosterone, and androstenedione in ovine follicular fluid during growth and atresia of ovarian follicles. Biology of Reproduction 24 105-113.

Charpentier AH, Bednarek AK, Daniel RL, Hawkins KA, Laflin KJ, Gaddis S, MacLeod MC \& Aldaz CM 2000 Effects of estrogen on global gene expression: identification of novel targets of estrogen action. Cancer Research 60 5977-5983.

Cheng G, Weihua Z, Makinen S, Makela S, Saji S, Warner M, Gustafsson JA \& Hovatta O 2002 A role for the androgen receptor in follicular atresia of estrogen receptor beta knockout mouse ovary. Biology of Reproduction 66 77-84.

Cooke PS, Buchanan DL, Young P, Setiawan T, Brody J, Korach KS, Taylor J, Lubahn DB \& Cunha GR 1997 Stromal estrogen receptors mediate mitogenic effects of estradiol on uterine epithelium. PNAS 94 6535-6540.

Couse JF \& Korach KS 1999a Reproductive phenotypes in the estrogen receptor-alpha knockout mouse. Annals of Endocrinology 60 143-148.

Couse JF \& Korach KS $1999 b$ Estrogen receptor null mice: what have we learned and where will they lead us? Endocrine Reviews 20 358-417.

Couse JF, Hewitt SC, Bunch DO, Sar M, Walker VR, Davis BJ \& Korach KS 1999 Postnatal sex reversal of the ovaries in mice lacking estrogen receptors alpha and beta. Science 286 2328-2331.

Crumeyrolle-Arias M, Scheib D \& Aschheim P 1976 Light and electron microscopy of the ovarian interstitial tissue in the senile rat: normal aspect and response to HCG of 'deficiency cells' and 'epithelial cords'. Gerontology 22 185-204.

Desvages G \& Pieau C 1992 Aromatase activity in gonads of turtle embryos as a function of the incubation temperature of eggs. Journal of Steroid Biochemistry and Molecular Biology 41 851-853.

Desvages G, Girondot M \& Pieau C 1993 Sensitive stages for the effects of temperature on gonadal aromatase activity in embryos of the marine turtle Dermochelys coriacea. General and Comparative Endocrinology 92 54-61.

Diczfalusy E \& Fraser IS 1998 The discovery of reproductive steroid hormones and recognition of their physiological roles. In Estrogens and Progesterones in Clinical Practice, pp 3-18. Eds IS Fraser, RPS Jansen, RA Lobo \& MI Whitehead. London: Churchill Livingstone.

Drummond AE \& Findlay JK 1999 The role of estrogen in folliculogenesis. Molecular and Cellular Endocrinology 151 57-64.

Dupont S, Krust A, Gansmuller A, Dierich A, Chambon P \& Mark M 2000 Effect of single and compound knockouts of estrogen receptors alpha (ERalpha) and beta (ERbeta) on mouse reproductive phenotypes. Development 127 4277-4291.

Engle E 1946 Tubular adenomas and testis-like tubules of the ovaries of aged rats. Cancer Research 6 578-582.

Findlay JK 1993 An update on the roles of inhibin, activin, and follistatin as local regulators of folliculogenesis. Biology of Reproduction 48 15-23.

Fisher CR, Graves KH, Parlow AF \& Simpson ER 1998 Characterization of mice deficient in aromatase (ArKO) because of targeted disruption of the cyp19 gene. PNAS 95 6965-6970.

Hashimoto N, Kubokawa R, Yamazaki K, Noguchi M \& Kato Y 1990 Germ cell deficiency causes testis cord differentiation in reconstituted mouse fetal ovaries. Journal of Experimental Zoology 253 61-70.

Hillier SG \& Tetsuka M 1997 Role of androgens in follicle maturation and atresia. Baillieres Clinical Obstetrics and Gynaecology 11 249-260.

Hirshfield AN 1991 Development of follicles in the mammalian ovary. International Reviews of Cytology 124 43-101.

Hisaw FL 1947 Development of the graafian follicle and ovulation. Physiological Reviews 27 95-119.

Honda S, Harada N, Ito S, Takagi Y \& Maeda S 1998 Disruption of sexual behavior in male aromatase-deficient mice lacking exons 1 and 2 of the cyp19 gene. Biochemical and Biophysical Research Communications 252 445-449. 
Hsu SY \& Hsueh AJ 2000 Tissue-specific Bcl-2 protein partners in apoptosis: an ovarian paradigm. Physiological Reviews 80 593-614.

Jarred RA, McPherson SJ, Bianco JJ, Couse JF, Korach KS \& Risbridger GP 2002 Prostate phenotypes in estrogen-modulated transgenic mice. Trends in Endocrinology and Metabolism 13 163-168.

Jensen EV \& DeSombre ER 1973 Estrogen-receptor interaction. Science 182 126-134.

Jost A, Vigier B, Prepin J \& Perchellet JP 1973 Studies on sex differentiation in mammals. Recent Progress in Hormone Research 29 $1-41$.

Krege JH, Hodgin JB, Couse JF, Enmark E, Warner M, Mahler JF, Sar M, Korach KS, Gustafsson JA \& Smithies O 1998 Generation and reproductive phenotypes of mice lacking estrogen receptor beta. PNAS 95 15677-15682.

Kuiper GGJM, Enmark E, Pelto-Huikko M, Nilsson S \& Gustafsson JA 1996 Cloning of a novel estrogen receptor expressed in the rat prostate and ovary. PNAS 93 5925-5930.

Kumar TR, Wang Y, Lu N \& Matzuk MM 1997 Follicle stimulating hormone is required for ovarian follicle maturation but not male fertility. Nature Genetics 15 201-204.

Liu MM, Albanese C, Anderson CM, Hilty K, Webb P, Uht RM, Price RH Jr, Pestell RG \& Kushner PJ 2002 Opposing action of estrogen receptors $\alpha$ and $\beta$ on cyclin D1 gene expression. Journal of Biological Chemistry 277 24353-24360.

Lubahn DB, Moyer JS, Golding TS, Couse JF, Korach KS \& Smithies O 1993 Alteration of reproductive function but not prenatal sexual development after insertional disruption of the mouse estrogen receptor gene. PNAS 90 11162-11166.

McDonnell DP, Chang CY \& Norris JD 2000 Development of peptide antagonists that target estrogen receptor-cofactor interactions. Journal of Steroid Biochemistry and Molecular Biology 74 327-335.

McDonnell DP, Chang CY \& Norris JD 2001 Capitalizing on the complexities of estrogen receptor pharmacology in the quest for the perfect SERM. Annals of the New York Academy of Sciences 949 $16-35$.

McKenna NJ, Lanz RB \& O’Malley BW 1999 Nuclear receptor coregulators: cellular and molecular biology. Endocrine Reviews 20 321-344.

McLaren A 1991 Development of the mammalian gonad: the fate of the supporting cell lineage. Bioessays 13 151-156.

Maxson WS, Haney AF \& Schomberg DW 1985 Steroidogenesis in porcine atretic follicles: loss of aromatase activity in isolated granulosa and theca. Biology of Reproduction 33 495-501.

Merchant H 1975 Rat gonadal and ovarian organogenesis with and without germ cells. An ultrastructural study. Developmental Biology 44 1-21.

Merchant-Larios H \& Centeno B 1981 Morphogenesis of the ovary from the sterile W/Wv mouse. Progress in Clinical Biological Research 59B 383-392.

Monget P \& Bondy C 2000 Importance of the IGF system in early folliculogenesis. Molecular and Cellular Endocrinology 163 89-93.

Ng LJ, Wheatley S, Muscat GE, Conway-Campbell J, Bowles J, Wright E, Bell DM, Tam PP, Cheah KS \& Koopman P 1997 SOX9 binds DNA, activates transcription, and coexpresses with type II collagen during chondrogenesis in the mouse. Developmental Biology 183 108-121.

Onate SA, Tsai SY, Tsai MJ \& O'Malley BW 1995 Sequence and characterization of a coactivator for the steroid hormone receptor superfamily. Science 270 1354-1357.

Pieau C, Girondot M, Richard-Mercier N, Desvages G, Dorizzi M \& Zaborski P 1994 Environmental Control of Gonadal Differentiation. Cambridge: Cambridge University Press.

Pincus G, Rock J, Garcia C-R, Rice-Wray E, Paniagua M, Rodriguez B \& Pedras R 1958 Fertility control with oral contraception. American Journal of Obstetrics and Gynecology 75 1333-1346.
Reynaud K \& Driancourt MA 2000 Oocyte attrition. Molecular and Cellular Endocrinology 163 101-108.

Richards JS 2001 Perspective: the ovarian follicle - a perspective in 2001. Endocrinology 142 2184-2193.

Richards JS, Sharma SC, Falender AE \& Lo YH 2002 Expression of FKHR, FKHRL1, and AFX genes in the rodent ovary: evidence for regulation by IGF-I, estrogen, and the gonadotropins. Molecular Endocrinology 16 580-599.

Robker RL \& Richards JS 1998a Hormone-induced proliferation and differentiation of granulosa cells: a coordinated balance of the cell cycle regulators cyclin D2 and p27 Kip1. Molecular Endocrinology 12 924-940.

Robker RL \& Richards JS $1998 b$ Hormonal control of the cell cycle in ovarian cells: proliferation versus differentiation. Biology of Reproduction 59 476-482.

Sar M \& Welsch F 1999 Differential expression of estrogen receptorbeta and estrogen receptor-alpha in the rat ovary. Endocrinology $\mathbf{1 4 0}$ 963-971.

Scaramuzzi RJ, Adams NR, Baird DT, Campbell BK, Downing JA, Findlay JK, Henderson KM, Martin GB, McNatty KP, McNeilly AS et al. 1993 A model for follicle selection and the determination of ovulation rate in the ewe. Reproduction Fertility and Development $\mathbf{5}$ 459-478.

Sharara FI, Seifer DB \& Flaws JA 1998 Environmental toxicants and female reproduction. Fertility and Sterility 70 613-622.

Sharma SC, Clemens JW, Pisarska MD \& Richards JS 1999 Expression and function of estrogen receptor subtypes in granulosa cells: regulation by estradiol and forskolin. Endocrinology $\mathbf{1 4 0}$ $4320-4334$

Swan SH 2000 Intrauterine exposure to diethylstilbestrol: long-term effects in humans. Apmis 108 793-804.

Toda K, Takeda K, Okada T, Akira S, Saibara T, Kaname T, Yamamura K, Onishi S \& Shizuta Y 2001 Targeted disruption of the aromatase P450 gene (Cyp19) in mice and their ovarian and uterine responses to 17 beta-oestradiol. Journal of Endocrinology $\mathbf{1 7 0}$ 99-111.

Toda K, Miyaura C, Okada T \& Shizuta Y 2002 Dietary bisphenol A prevents ovarian degeneration and bone loss in female mice lacking the aromatase gene (Cyp19). European Journal of Biochemistry 269 2214-2222.

Vaillant S, Magre S, Dorizzi M, Pieau C \& Richard-Mercier N 2001 Expression of AMH, SF1, and SOX9 in gonads of genetic female chickens during sex reversal induced by an aromatase inhibitor. Developmental Dynamics 222 228-237.

Vidal VP, Chaboissier MC, de Rooij DG \& Schedl A 2001 Sox9 induces testis development in XX transgenic mice. Nature Genetics 28 216-217.

Weihua Z, Saji S, Makinen S, Cheng G, Jensen EV, Warner M \& Gustafsson JA 2000 Estrogen receptor (ER) beta, a modulator of ERalpha in the uterus. PNAS 97 5936-5941.

Weihua Z, Makela S, Andersson LC, Salmi S, Saji S, Webster JI, Jensen EV, Nilsson S, Warner M \& Gustafsson JA 2001 A role for estrogen receptor beta in the regulation of growth of the ventral prostate. PNAS 98 6330-6335.

Wilson JD, Griffin JE, George FW \& Leshin M 1981 The role of gonadal steroids in sexual differentiation. Recent Progress in Hormone Research 37 1-39.

Windahl SH, Hollberg K, Vidal O, Gustafsson JA, Ohlsson C \& Andersson G 2001 Female estrogen receptor beta-/- mice are partially protected against age-related trabecular bone loss. Journal of Bone and Mineral Research 16 1388-1398.

Zhou J, Kumar TR, Matzuk MM \& Bondy C 1997 Insulin-like growth factor I regulates gonadotropin responsiveness in the murine ovary. Molecular Endocrinology 11 1924-1933.

Received in final form 25 June 2002

Accepted 26 June 2002 